\title{
Resilience in interior architecture education: Distance universal design learning in the COVID- 19 pandemic
}

\author{
İlkay Dinç Uyaroğlu*(i)
}

\begin{abstract}
The COVID-19 pandemic has significantly affected all levels of education all over the World. In Turkey, on March 16, 2020, the decision of distance education was taken in higher education sharply. This necessity had caused urgent adaptation to the distance education process, which resulted in changing the courses' curriculums in parallel with the emergence of new teaching and learning strategies especially in applied programs such as interior architecture. This process has tested the 'resilience' of the education system explicitly. Resilience means an ability of a community, system, or individual to 'adapt' and 'transform' in the case of varied facts causing any disruptive situation in the existing system. The pandemic has taught the education community about 'adaptation' and 'transformation' through implementing diverse learning tools and responses to complex circumstances, especially in applied courses. With the end of the pandemic, the instructors experiencing the face-to-face education environment anew will sustain it with the lessons from the pandemic undoubtedly. This study aims to discuss the concept of 'resilience' with its basic dimensions, 'adaptation' and 'transformation', in interior architecture education by focusing on the experiences, limitations, and potentials experienced in the distance education process. It specifically dwells on teaching and learning experiences of Universal Design (UD) course conducted in the Department of Interior Architecture and Environmental Design, Atılım University, Ankara in the 2020 Spring term when the first and urgent adaptation to distance education had been experienced. The evaluation process is supported with the obtained qualitative data, with results suggesting that all students gained useful insights by experiencing multiple dialogue environments in various ways of learning into how they can incorporate inclusivity into future designs. This study displays that it is crucial that the distance UD learning process open to interactive dialogue among students, experts, instructors, and users to design inclusive spaces welcoming all people without discrimination. It argues that there have been potential improvements about adaptation and transformations of educational approaches within the pandemic, but in interior architecture education as applied design education, the importance and necessity of experiential learning in bodily and collective communication has been deeply proven.
\end{abstract}

Keywords: COVID-19, distance education, resilience, universal design Learning, interior architecture. 


\section{Introduction}

Resilience is an important concept to define the quality of life in the twenty-first century (Trogal, Bauman, Lawrence \& Petrescu, 2019). It has been contextualized within the scholarship of different disciplines to respond to diverse community needs. In architecture discipline, resilience is defined as a key concept to enhance the empowerment of the community for readiness, response, and adjust to any risks or changes by making a transformative contribution to the development of the built environment and community (Trogal, Bauman, Lawrence \& Petrescu, 2019). Social justice, social and climate impact on architecture, urban crises and risk reduction, disaster-resilient architectural design, and performance-based architectural design are some spheres addressed in this sense. Resilience has also been highlighted in the field of learning in terms of the significance of adaptation and self-organisation within an educational system (Folke et al., 2010). Addressing the collective effects of architectural design and education towards resilience, Campos (2020, p.1) highlights that "architecture, properly planned, is a vital ally of resilience, by adding an "educational" value that enriches well-being and motivates learning". The COVID-19 Pandemic process which we have been living in has revealed the importance of resilience in architectural education.

In addressing resilience in interior architecture education, this study specifically focuses on Universal Design (UD) learning. Universal Design is a design concept that addresses designing products, buildings, interiors, exteriors, and all parts of built environments equitably used by all people to the greatest extent possible (Ostroff, 2011). Since its philosophy is based on the 'social justice' context (Ostroff, 2011) that is one of the global concerns in architecture within the same manner of 'resilience' (Trogal, Bauman, Lawrence \& Petrescu, 2019), the UD learning process also deserves much attention.

While addressing current complex global concerns, specifically humanitarian design in architecture education, Brogden (2020) describes that it needs to incorporate transdisciplinary and collaborative design methods within the 'process-inherent' paradigm instead of 'product-oriented' one. Herein, the importance of social and physical dialogue between people (instructors, students, etc.) and spaces for the success of education becomes even more evident during the Pandemic (Cengizkan, 2021).

On March 16, 2020, at the middle of the education term, with the decision on the transition of face-to-face to distance education in all higher education institutes in Turkey, education was suspended for two weeks in Atılım University, Ankara. Meanwhile, the necessary infrastructure works were carried out and the preparations for the distance education system were completed. In this sense, the theoretical and applied course content prepared within the framework of face-toface education was reconsidered within the structure of the distance education model and reconstructed with new content.

By addressing 'resilience' in education, this study aims to evaluate the constructive impact of the worldwide shutdown on UD learning in the Spring Semester of the 2020-2021 Academic Year in the Department of Interior Architecture and Environmental Design in Atılım University. It dwells on designing and implementing various ways of face-to-face and remote teaching and learning based on sustaining an efficient learning process in each circumstance. The method of the study is based on qualitative research. The students' written studies, visual presentations, discussions in each course, their written and verbal reflections on a seminar, and the general learning process are all sources to be analysed contently. Additionally, at the end of the semester, the students presented their final studies with the evaluation of the process in an online panel discussion in responding to the question: "Which way(s) you benefit from to learn and embody the Universal Design knowledge?" Based on these issues, the study concludes with the critical evaluation of the Universal Design learning process in highlighting resilient learning environments in the sphere of interior architecture education. This study claims that the experienced benefits and challenges of 
this process will shed light on the future of interior architecture education within a post-pandemic world, which would contribute to the development of resilient education.

\section{Resilience in Interior Architecture Education}

The term 'resilience' has its roots in the Latin verb 'resilire' which means 'to jump back' or 'to recoil'. ${ }^{1}$ Resilience is a concept that is used for varied phenomena causing any disruptive situation in the existing system (Campos, 2020, p. 1). It is described as the ability of societies and systems to withstand and adapt to changes or deteriorations (Campos, 2020, p. 1). Resilience is comprehensively defined by the United Nations International Strategy for Disaster Risk Reduction as follows:

The ability of a system, community or society exposed to hazards to resist, absorb, accommodate, adapt to, transform and recover from the effects of a hazard in a timely and efficient manner, including through the preservation and restoration of its essential basic structures and functions through risk management (UNDRR, 2021).

This definition displays that resilience is based on the level of tolerance of the existing system and community in terms of sustaining functions and experiences within hazardous changes or deteriorations. Walker et al. (2004) and Folke et al. (2010) categorizes resilience into three aspects: 'resilience', 'adaptability', and 'transformability' which are interrelated across various scales. While they define 'adaptability' as the capability to adjust reactions to any altering situation and in this manner, to allow for progress along with it, they express 'transformability' as "the capacity to cross thresholds into new development trajectories" (Folke et al., 2010). Herein, it is important for a resilient education that the community and system in higher education would adapt to and transform by the changes in unplanned and undesirable conditions (Waxman, Gray \& Padron, 2003).

For John Dewey, education is a life-long process in which all dimensions of life involving human, natural, and built artifacts affect the learning process holistically. (Dewey, 1916, p. 19-20). His thought addresses the effective way of learning through a learning environment that is directly or indirectly perceived by all sensory, tactile, visual, and auditory senses. When we consider Dewey's (1916) approach on education together with the way the Folke et al. (2010) handles resilience, it can be noticed that the context of resilience is founded on the life-long interaction among person(s) and their environment in requiring experiences on 'adaptation' and 'transformation' as parts of the learning process.

Campos (2020, p. 3) expresses that the actual physical environment more specifically educational one has crucial importance to sustain the culture of education and increase learning in terms of advancing effect, community, learning, and environmental sustainability. This becomes even more important when it comes to architectural education. Gehl's $(2011$, p. 41) thoughts on "life between buildings" well express it in such a way that people confront good conditions and opportunities in environments by which they have a variety of collected experiences by adjusting and adapting to the environment and its spatial functions. Learning 'in' and 'from' spaces is a very crucial aspect but could not have been experienced during the Pandemic sufficiently. Herein, it is thought for this study that although the lessons have to be carried out in the virtual environment, the house can be thought of as a tool ready for detailed research-for the things that we think we know but have a lot of unknown.

The capability of architectural education to respond to changes in different ways is essential for a resilient educational system/environment (Campos, 2020, p. 9). In referring to Folke et al. (2010), the ways of responding to changes are central to 'adaptation' and 'transformation' to the

\footnotetext{
${ }^{1}$ Resilience. Retrieved on April 12, 2021 from https://www.merriam-webster.com/dictionary/resilience\#h1.
} 
experienced process. This implies the provision of a transformable educational environment either for a planned or abrupt learning process that will enable students to participate and communicate interactively in any condition. Experienced virtual educational environment that we are obliged in the pandemic can be described as a way of abrupt changing in need of new dialogue and collaborative learning environment. Transforming into distance education environments enhances the (re)development of communication as well as the need for it, which would be an advantage of Page 237 this global calamity. This has caused the adoption of new learning tools and processes and the experience of various communication opportunities, which supports resiliency in interior architecture education.

The context of an inclusive spatial environment is also a critical theme in highlighting resilience in architecture as well as education. Equitable access in cities is so crucial that every member of communities would fully and equitably participate in social life to the greatest extent possible (Imrie \& Hall, 2001). In defining resilience, Laboy and Fannon (2016) highlight the context of 'socioecological (adaptive) resilience' which points out the role of architecture in sustaining social and cultural adaptation of communities in the future. Especially nowadays, when health and well-being are vital goals in public life, the design of all parts of the urban environments, involving interiors, deserves considerable attention.

Resilience is a topic that we start to discuss with the events that happen outside of 'normal'. When we are faced with a situation outside the order, we are accustomed to, it comes to the fore how we can respond and tolerate the negativities experienced. In the modern social-based approach, disability is conceptualised as a 'normal' experience (WHO, 2001) and thereby ensuring accessibility for all in an equal manner should be a standard action in designing spaces. However, in the case of Turkey, we still cannot apply inclusive design principles in an appropriate way even in public spaces. Therefore, the integration of the Universal Design concept into the architecture curriculum is a must issue to create resilient interior or exterior spaces in cities.

Individual resilience against adversities has also been widely discussed in the field of education (Waxman, Gray \& Padron, 2003). This is also valid for resilience in interior architecture education. It involves both instructors' and students' ability to cope with difficulties, resistance to adversity, adapting to abnormal situations, and maintaining wellbeing and motivation to learn/teach (Waxman, Gray \& Padron, 2003). Herein, it should be noted that educational resilience is based on the social context as much as individual one (Rutter, 1993, p. 626). For learning from other sources or people in supporting each other advances interactive dialogue among whole educational community. In this sense, during the process of 'stay at home', social, spatial, psychological, and technical means of conducting online courses considerably affect the individual learning/teaching process.

Table 1 Important themes in resilient interior architecture education.

\begin{tabular}{l|l}
\hline \multicolumn{1}{c|}{ Adaptive acts } & \multicolumn{1}{c}{ Transformative acts } \\
\hline Social and psychological preparation & Arranging a new learning/ communication environment \\
\hline Meeting the technological equipment & $\begin{array}{l}\text { Developing the course content according to the distance } \\
\text { education system }\end{array}$ \\
\hline Knowing the virtual learning environment tools & Applying appropriate learning methods \\
\hline Having suitable spatial attributes & Performing appropriate learning practices \\
\hline Creating new dialogue environments & \\
\hline Adjusting to the new curriculum and learning tools & \\
\hline \multicolumn{2}{c}{ Students } \\
\hline \multicolumn{2}{c}{ Academicians } \\
\hline
\end{tabular}

Based on the above discussions and the lived experiences in the context of this study, Table 1 presents the important issues about resilient interior architecture education for the fact that the education community (for both educators and learners) can be 'adaptive' and 'transformative' 
when facing complexity, uncertainty, vulnerability, and extremely rapid change during the COVID19 Pandemic.

\section{Universal Design in Interior Architecture Education}

Universal Design (UD) is a concept advocating that all parts of the built environment should be equally accessible and safe to all users without making any discrimination due to their different (dis)abilities (Ostroff, 2011). Its well-known and appreciated seven principles are (1) Equitable use, (2) Flexibility in Use, (3) Simple and intuitive (4) Perceptible information, (5) Tolerance for error, (6) Low physical effort, (7) Size and space for approach and use (Ostroff, 2011). Through their implementations in spaces, it appreciates the 'full participation' and 'social inclusion' of all community members including people with diverse (dis)abilities in all spheres of public life (Heylighen, Van der Linden \& Van Steenwinkel, 2017; Ostroff, 2011). UD philosophy needs to be integrated into varied design disciplines involving design education which are dwelled on a relationship between human and spatial environment in contributing a sustainable life (Ostroff, 2011, p.1.9). Among them, architecture has a crucial responsibility for creating an inclusive public life without causing any discriminatory situation due to drawbacks in the spatial environment. This is based on moral responsibility for sustaining human rights rather than a choice (Sungur Ergenoğlu, 2015, p. 1398; Yılmaz, 2018, p. 12). In the context of interior design, interior architects should have an inclusive design vision to make interior spaces inclusively usable for all so that users with diverse ages and (dis)abilities can access to spaces independently and equitably. This enhances the inclusivity of spaces along with physical access and social dialogue within spaces (Heylighen, Van der Linden \& Van Steenwinkel, 2017).

Designing spaces with Universal Design philosophy is an obligation for human rights, which is dictated by national (e.g. Turkish Disability Law no 5378) and international legal documents (e.g. U.N. Convention on the Rights of Persons with Disabilities). However, the design decisions only dominated by laws, regulations, and standards are not sufficient to achieve an inclusive spatial environment. On the other hand, as Imrie (1996) suggests, many legal perspectives are vague and challenging to enforce. The design only under the pressure of specific legal necessities cannot address the big picture of spatial equity among societies (Imrie \& Hall, 2001). To create real inclusive spaces, it is essential to internalize and embody the UD knowledge in whole phases of a design process from the beginning to the end of the design and during the implementation phase (Tutal, 2016).

Interior architects should have required knowledge about Universal Design philosophy but most importantly, they should know how they act through design decisions in its notion instead of only complying with the design codes specified by the legislative documents. Therefore, the interior architecture education curriculum needs to holistically integrate the UD knowledge acquisition process (Afacan, 2011; Helvacıŏlu \& Kahraman, 2012). Designers' responsibility on socioenvironmental issues is an important theme in the socio-ecological (adaptive) aspects of resilience (Laboy \& Fannon, 2016). Developing knowledge, ways of thinking, and practices on the design of inclusive spaces work for building a sustainable future. For its success, learning strategies embedded into the design education curriculum deserve more attention.

\subsection{Learning Strategies}

There have been many studies in the literature that addressing teaching and learning approaches to increase the efficiency of the learning process in advancing the knowledge acquisition and awareness of the Universal Design concept in design education. The adopted approaches differ widely in terms of scale and impact: A degree programme, course section for a certificate programme, research project, interdisciplinary projects, student awards organisations (Ostroff, 2003). In interior architecture education, UD learning is generally limited to one or two elective courses in the curriculum (Helvacıoğlu \& Kahraman, 2012, p. 101). UD learning should be 
an inseparable part of the overall four-year curriculum content, especially in the design studios and lectures (Afacan, 2011). This can contribute to developing both a resilient education model and the creation of resilient spaces and life.

Various learning approaches guide the acquisition of Universal Design knowledge in an effective way in architectural education. The study of Altay and Demirkan (2014) indicates that 'empathy' is a useful learning tool by which interior architecture students develop their knowledge and awareness of inclusive design in terms of both individual and community aspects. However, "future work is required giving details on how exactly designers can engage in deep and meaningful exchanges or dialogues with people" (Strickfaden, Devlieger \& Heylighen, 2009). Beyond being a one-sided understanding of spatial needs of absent users, the development of a thinking process contributing to the deepening of design knowledge by creating a mutual dialogue environment should be supported (Strickfaden, Devlieger \& Heylighen, 2009). In this sense, Dong (2010) highlights the active participation of users in the design process to expand students' empathic perspectives to the extent possible. Ostroff (1997) significantly emphasizes users as 'experts' on the use of their spaces so their varied thoughts and experiences should be integrated into the whole design process. In essentially respecting user participation in the design process, action/participative research and co-designing in a collaborative design process also enhances an interactive dialogue between designers/researchers, stakeholders, and users (Cassim \& Dong, 2007).

It is argued in this study that teaching Universal Design must involve multiple learning methods in a way that supports each other to prepare students for solving complex design problems more appropriately and sufficiently (Cassim \& Dong, 2007). This approach would create resiliency in interior architecture design education with regards to responding to diverse learning styles of students and acquiring tested knowledge by experiencing diverse learning tools. The Universal Design course evaluated in this study was aimed to be implemented through addressing theoretical and practical ways of knowledge acquisition in a collaborative design approach. From this viewpoint, the research/design methods mentioned above are aimed to be fulfilled transversally according to the theme of final design projects. For instance, when empathy modelling is utilised as a learning tool, the participative research approach is also integrated into the learning process to develop knowledge acquisition by the crosscheck of research findings. However, the COVID-19 pandemic taught us in a very striking way that it is necessary to consider the effectiveness of learning process in the distance education process for achieving a resilient teaching/learning process.

\section{The Method of the Study}

This study presents the teaching and learning experiences of the Universal Design course conducted by the author in the 2019-2020 Spring Semester in the Department of Interior Architecture and Environmental Design at Atılım University, Ankara. It is aiming at the evaluation of the learning process of the Universal Design course when the global pandemic sharply mandated distance education at the middle of the semester. 17 interior architecture students $\left(3^{\text {rd }}\right.$ - and $4^{\text {th }}$ year students) enrolled in the course and 16 ( 1 is NA) finished the course successfully. The evaluation process of this study was supported by the obtained qualitative data gained from the weekly open-ended discussions and questions. The visual and verbal presentations of the students' research/works and their thoughts about their adaptation and transformation in the learning process were assessed qualitatively. In each course, the comments on awareness, acknowledging, and shifting in decisions were noted and evaluated by the instructor/author. They were evaluated within an interpretive approach, with results suggesting that all students gained useful insights by crosscutting discussions in multiple ways of research into how they can incorporate inclusivity into future designs. 


\subsection{Hybrid Universal Design (UD) Learning Process}

Universal Design (UD) course, focused on in this study, is an elective course with $(1+2+0) 2$ Credits, 4 ECTS Credits. The main objectives of the course are as follows:

- To provide students with information about interior and environmental design that respect individuals with different needs, including people with diverse disabilities, elders, and children.

- To support them to have detailed information about both social and physical dimensions of Universal Design philosophy by analysing samples of inclusive spaces.

- To enable students to experience participatory and experiential design tools, to reach a level which they can apply the best possible inclusive design solutions.

To accomplish embodying UD knowledge into the learning process efficiently, the schedule was formulated to incorporate theoretical and practical design dimensions in an interactive studio atmosphere. In accomplishing the course's objectives, students were expected to understand, analyse and comprehend a variety of complex spatial problems and phenomena that result in discrimination in spaces.

In the middle of the semester, when distance education had been mandatory, it was essential to adopt the course curriculum to the distance education process in responding to the objectives of the course. The forced switch to remote teaching/learning has generally encouraged and forced instructors to redesign their methods and practices of teaching/learning. In this process, creative ways to translate the face-to-face course curriculum into the distance education format were developed. Instructors tried to convert their resources to digital format and put them on the online learning management system of the university. It should be stated that there was a great burden on the instructors in the preparation process to get through it with less damage.

In the context of this study, to enhance the best learning experiences possible, it is essential to make a powerful connection between the learning objectives of the course and the ways of thinking and learning process for responding to the inclusiveness of spaces. If the students get acquainted with various ways of design thinking with the help of diverse learning tools, they might develop a deep-thinking process in experiencing 'multiple intelligences in the design process' ( $D$ 'Souza, 2007). Emphasizing todays' and even future education approaches, 'Practices', 'Crosscutting Concepts', and 'Core Ideas' are three major interconnecting dimensions (Duschl, 2012). Valuing it, opening the door to diverse intellectual discussions through linking other disciplines had been appreciated during the learning process. Discussions on disability in the products of cinema, art, science, and literature (especially, letters of people with disabilities) in addition to architecture and city planning were involved in the learning process. Instead of explaining the existing knowledge as it was, it was aimed to question the concepts that emerged in the light of these discussions. By this, the students were expected to confront unknown and unrealised facts, concepts, and experiences in life as well as scientific knowledge. In appreciating these ideas, in the aspect of resilient education, flexibly changed ways of teaching were prioritized rather than the static disciplinary ways of it in forming a curriculum.

\subsubsection{Curriculum before Pandemic}

The course starts with theoretical discussions on the concept of Universal Design (UD) with its definition, historical development, and the context of the UD principles. It was carried out through the collaborative discussions guided by the instructor's presentations, assigned readings, and varied daily life experiences. Below topics in order were aimed to be discussed and understood in depth:

1. The relationship between disability and spatial design with its physical and social aspects;

2. The concept and principles of UD and their development; 
3. Examining the relationship of UD philosophy with the concepts of social integration, equal participation, social justice, and sustainability;

4. National and international accessibility standards;

5. Design principles for persons with mobility, visual, and hearing impairments;

6. Inclusive and participatory design methods and approaches.

By addressing this theoretical framework, it was aimed for students to understand and comprehend the place of the concept of Universal Design in the big picture- sustainable design, social sustainability, and quality of life- beyond the point of view reduced to merely disability. Discussions on 'equality' and 'justice' in the city were carried out within the wider context, and the dimensions of spatial justice in terms of different times, scales, and users were discussed. It is thought that handling the UD in this framework will lead to the realization of inclusive designs with a more holistic view.

After addressing the above contexts in the face-to-face class environment, the students were expected to prepare a research report which would display the level of their understanding of the UD philosophy. With the start of urgent distance education, they presented their reports which were evaluated as a mid-term exam with the help of Moodle (the university's learning management system). After that, deficiencies were evaluated and addressed together in an online class.

\subsubsection{Transformed Curriculum due to the Urgent Distance Education}

The next phase resided the experiential learning process to provide students with the knowledge of the users' real-life desires and preferences in experiencing spaces by 'empathy', 'participatory observation', and 'close dialogue with users'. In this phase, the students firstly experienced in-depth behavioural analysis of their houses concerning the activities, preferences, and limitations of the family members. They were expected to address the relationships of the behavioural patterns of users- each member of their family- and their daily life activities in the house by using participatory observation and dialogue with their family members. This also involved the preferences of the users in highlighting spatial deficiencies and suggestions. Then, utilizing empathy modelling, they evaluated their houses' spatial attributes according to the needs of unfamiliar users, those with total visual loss and a wheelchair. As a result of their experiences, spatial analyses (within three scaled method- deterrent, moderate, and inclusive) and suggested (re)design solutions in UD approach were presented. In each week, the students were expected to share their experiences and thoughts with their analysis and observations. Secondly, they were expected to obtain experiences and thoughts of the person with a visual impairment within the home through an online lesson. The students tried to understand by asking their questions to her how the (possible) situations they discovered through the activity-participation relationship matched their findings.

Two main technical systems to enhance an effective distance learning environment had been used in this process: (1) the university's learning management system already in use, namely Moodle; (2) the software programme, Zoom, for enhancing the interactive virtual learning environment. All information exchange with students, homework delivery, discussions, questionanswer process, exams were carried out smoothly through Moodle and Zoom collaboratively.

The course ended with a submission of a research report and its presentation in an online lesson, which was evaluated as the final exam. At the end of the lesson, open-ended questions founded on the question of "which task(s) have been instructive for you to internalize the Universal Design knowledge?" were asked to the students on their whole learning experiences during the semester. Is the empathetic evaluation of their own house enough to learn a universally designed house? and Describe their opinions and learning process involving interviewing with the blind users' experiences? were some following questions in this regard. 
Table 2 Hybrid Universal Design Learning Process

\begin{tabular}{|c|c|c|c|c|}
\hline & STAGES & STUDENT TASK(S) & $\begin{array}{l}\text { LEARNING METHODS\& } \\
\text { RESOURCES }\end{array}$ & GAINED KNOWLEDGE \\
\hline 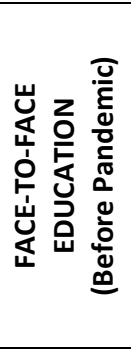 & STAGE 1 & $\begin{array}{l}\text {-Reading articles (involving } \\
\text { those of people with } \\
\text { disabilities) } \\
\text {-Watching and discussions on a } \\
\text { film } \\
\text {-Exploring news and social } \\
\text { media posts on the experiences } \\
\text { of people with disabilities } \\
\text {-Interpretations on samples }\end{array}$ & $\begin{array}{l}\text {-Moral reasoning } \\
\text {-Interpretation } \\
\text {-Critical evaluation } \\
\text {-Crosscutting discussion }\end{array}$ & $\begin{array}{l}\text {-Universal Design concept } \\
\text {-Quality of life } \\
\text {-Social equity, justice, } \\
\text { sustainability } \\
\text {-Inclusive design approach } \\
\text {-Implementation of the design } \\
\text { standards in an inclusive } \\
\text { manner }\end{array}$ \\
\hline \multirow{6}{*}{ 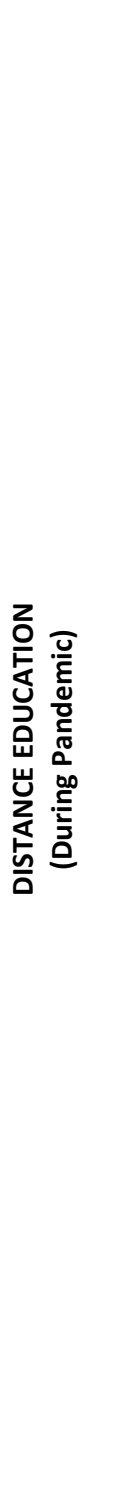 } & STAGE 2 & $\begin{array}{l}\text { Spatial analysis through the } \\
\text { family members' house } \\
\text { activities covering daily life } \\
\text { routines }\end{array}$ & $\begin{array}{l}\text {-Empirical reasoning } \\
\text {-Empathy (known } \\
\text { users) } \\
\text {-Observation } \\
\text {-Interviewing } \\
\text {-Sketching }\end{array}$ & $\begin{array}{l}\text {-Well-known users' experiences } \\
\text {-Diverse body-space and } \\
\text { activity-participation } \\
\text { relationships in the house } \\
\text {-Research methods } \\
\text {-Visual and verbal presentation } \\
\text { of the findings }\end{array}$ \\
\hline & STAGE 3 & $\begin{array}{l}\text { Understanding the activity- } \\
\text { participation pattern of a } \\
\text { wheelchair user in covering all } \\
\text { possible activities for each user } \\
\text { living in the house }\end{array}$ & $\begin{array}{l}\text {-Empirical reasoning } \\
\text {-Empathy (unknown } \\
\text { users) } \\
\text {-Observation } \\
\text {-Interviewing } \\
\text {-Making comparisons } \\
\text {-Sketching }\end{array}$ & $\begin{array}{l}\text {-Imaginary users' experiences } \\
\text {-Awareness of and knowing } \\
\text { diverse spatial necessities and } \\
\text { attributes for a wheelchair user } \\
\text {-Research methods } \\
\text {-Visual and verbal presentation } \\
\text { of the findings }\end{array}$ \\
\hline & STAGE 4 & $\begin{array}{l}\text { Understanding the activity- } \\
\text { participation pattern of a blind } \\
\text { user in covering all possible } \\
\text { activities for each user living in } \\
\text { the house }\end{array}$ & $\begin{array}{l}\text {-Empirical reasoning } \\
\text {-Empathy (unknown } \\
\text { users) } \\
\text {-Observation } \\
\text {-Interviewing } \\
\text {-Making comparisons } \\
\text {-Sketching }\end{array}$ & $\begin{array}{l}\text {-Imaginary users' experiences } \\
\text {-Awareness of and knowing } \\
\text { diverse spatial necessities and } \\
\text { attributes for a blind user } \\
\text {-Research methods } \\
\text {-Visual and verbal presentation } \\
\text { of the findings }\end{array}$ \\
\hline & STAGE 5 & $\begin{array}{l}\text {-Exploring the blind woman's } \\
\text { experiences in the house with } \\
\text { activity-participation aspects }\end{array}$ & $\begin{array}{l}\text {-Interviewing } \\
\text {-Empirical reasoning } \\
\text {-Making comparisons }\end{array}$ & $\begin{array}{l}\text { - Awareness of and knowing } \\
\text { the 'real' spatial needs for an } \\
\text { inclusive environment } \\
\text {-Recognising overlapping and } \\
\text { conflicting design matters in } \\
\text { comparing with the findings of } \\
\text { their empathetic evaluations } \\
\text { (3 } 3^{\text {rd }} \text { and } 4^{\text {th }} \text { stage) }\end{array}$ \\
\hline & STAGE 6 & $\begin{array}{l}\text {-Research on the good } \\
\text { examples of inclusive houses } \\
\text {-Evaluation of a selected } \\
\text { inclusive house by applying UD } \\
\text { Principles }\end{array}$ & $\begin{array}{l}\text {-Case study } \\
\text {-Critical evaluation } \\
\text {-Testing spaces with UD } \\
\text { Principles }\end{array}$ & $\begin{array}{l}\text {-Exploration of the } \\
\text { implementations of Universal } \\
\text { Design principles in diverse } \\
\text { samples }\end{array}$ \\
\hline & STAGE 7 & $\begin{array}{l}\text {-Propose spatial solutions to } \\
\text { make their houses universally } \\
\text { designed }\end{array}$ & $\begin{array}{l}\text {-Design thinking } \\
\text {-Application of UD } \\
\text { Principles } \\
\text {-Application of } \\
\text { technical standards }\end{array}$ & $\begin{array}{l}\text {-Experiencing UD thinking and } \\
\text { design process }\end{array}$ \\
\hline
\end{tabular}

\section{Evaluation of the UD Learning Process in the context of Resiliency}

In Stage 1, it was aimed that students be more active in each course's discussion as critical evaluators and independent learners searching for the inclusive design parameters (Table 2). This gave them having freedom of collective discussion on the Universal Design concept, but not limited to accessibility for people with disabilities. During theoretical discussions, the emerged contexts and ideas were so diverse that technical, physical, spatial, social, and even cultural dimensions were 
addressed with various spatial dimensions causing (dis)abling spaces. Designing inclusive built environments needs such a wide-ranging and cross-cutting design thinking process (D'Souza, 2007).

As a task of Stage 2, after transitioning from face-to-face to distance education, the students made a comprehensive analysis of their own houses within the framework of the activityparticipation analysis of their family members including themselves (Table 2). Daily life activities differ for each user living in the house, and the design problems and solutions also change. This task formed the basis for the awareness of the diversity in user needs as well as for the following assignments regarding the exploration of different user experiences.

In Stage 3 and 4 (Table 2), they investigated the extent to which a person with a wheelchair and visual impairment could (not) do each activity based on the activity-participation pattern of the house they studied in Stage 2 along with addressing suggested inclusive solutions to spatial deficiencies. Interpreting the axis of movement (circulation route) of a user with a wheelchair and total vision loss comparatively with their current activity route had made it possible to question the attitude and design principles required in the design of a barrier-free house. Students presented their research findings as a) Obstacle (Bad) b) Reasonable (Medium), and c) Inclusive (Good) in terms of activities, barriers for participation, and design solutions (Figure 1, 2).

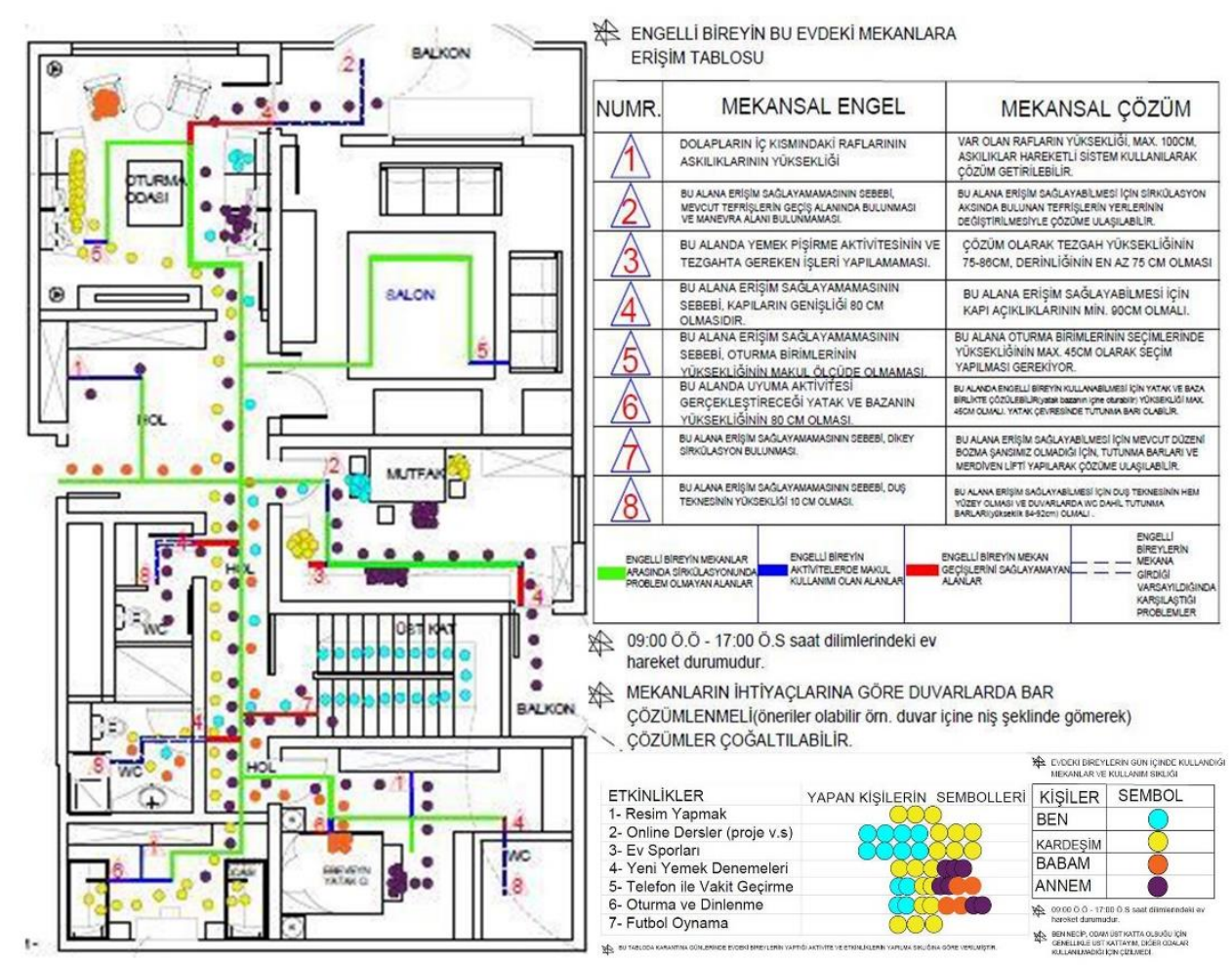

Figure 1 An example of the student's evaluation of his house for users with a wheelchair 


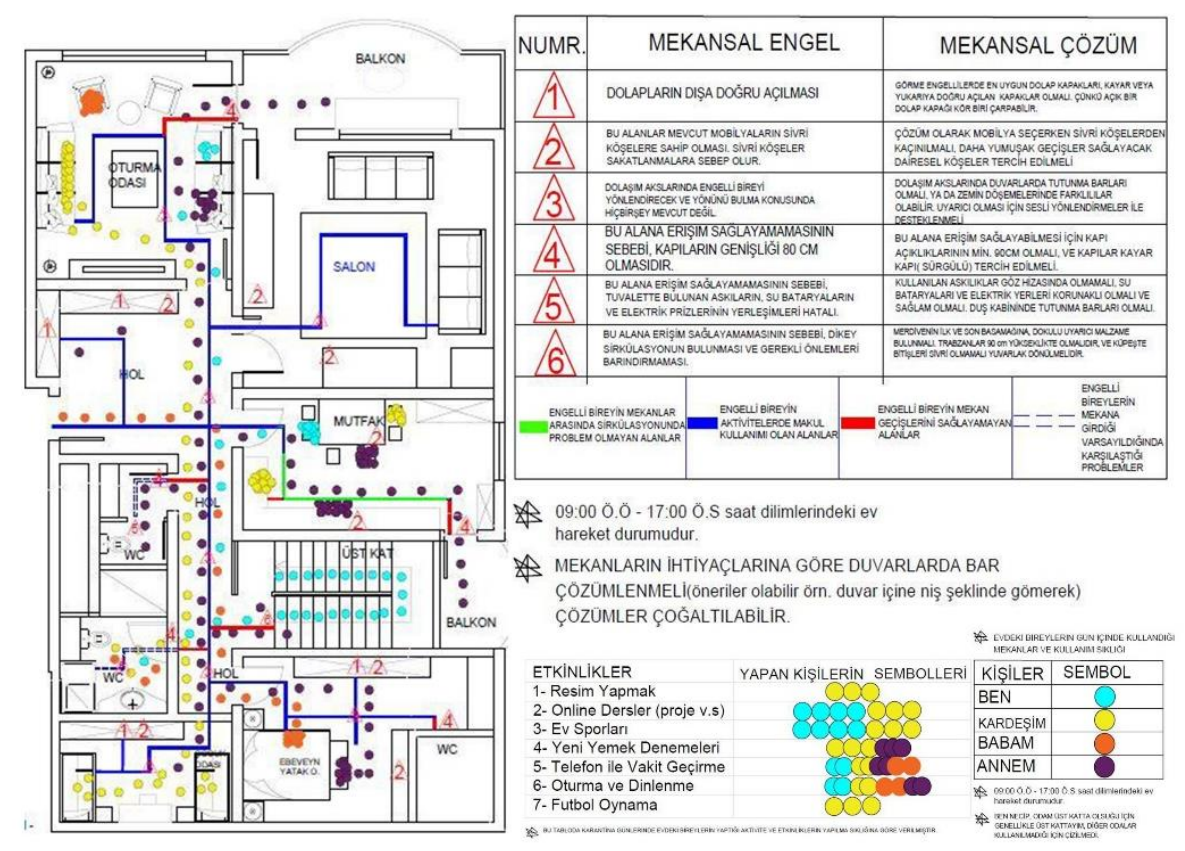

Page | 244

Figure 2 An example of the student's evaluation of his house for users with total vision loss

TEKERLEKLI SANDALYE KULLANICISININ HAREKET EKSENINI YORUMLAMAK
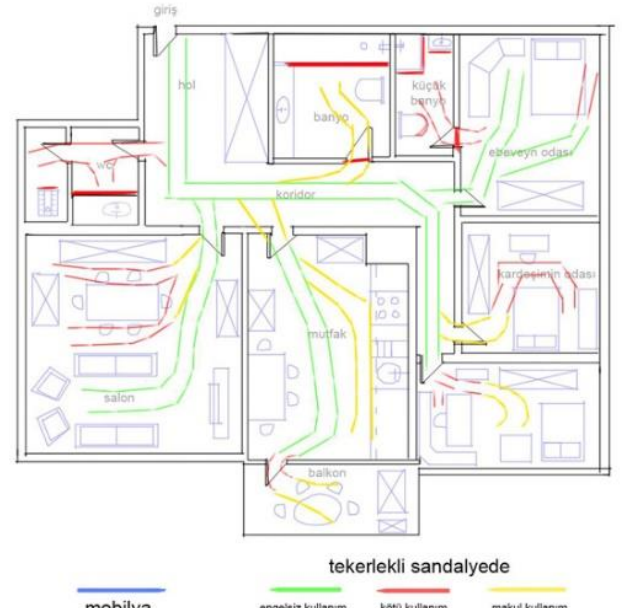

OLASI MEVCUT PROBLEMLER VE ÇÖZÜM ÖNERILERI

\begin{tabular}{|c|c|c|}
\hline meval & mekansal engel & mekansal çozum \\
\hline $\begin{array}{l}\text { wc } \\
\text {-tuvalet kullanımı } \\
\text {-el yikama } \\
\text {-temizilik malzemesi deposu } \\
\text {-çamașir makinesi kullanımı }\end{array}$ & $\begin{array}{l}\text { essik yaksekiligi } 5 \mathrm{~cm} \text { ve gecis } \\
\text { zortuguu var. } \\
\text { alan cok dar ve tekerlekli } \\
\text { sandalyenin manervasi zor. } \\
\text { destek alacak mevcut tedbir yok. }\end{array}$ & $\begin{array}{l}\text { dilvarlara modahele edilebilir. } \\
\text { destek alacak ve tutunacak } \\
\text { ekipmaniar yerlestirilmeli. } \\
\text { dolap konumu ile oynanmali. } \\
\text { eșik kaldirlimall. }\end{array}$ \\
\hline $\begin{array}{l}\text { salon } \\
\text {-misafirlerle yemek yeme alanı }\end{array}$ & $\begin{array}{l}\text { sandalyeler v } \\
\text { zor haie getir }\end{array}$ & $\begin{array}{l}\text { tefriste ufak degisisilikler ile } \\
\text { problem çozolebiliyor. }\end{array}$ \\
\hline $\begin{array}{l}\text { muttak } \\
\text {-mutfak eşyalarına ulaşım }\end{array}$ & $\begin{array}{l}\text { tezgah yoksekiligi iyi olmasina } \\
\text { rağmen dolaplara eişim zor. }\end{array}$ & $\begin{array}{l}\text { dolap derinligi ve dolap } \\
\text { yưksekigig daha azalmalt }\end{array}$ \\
\hline $\begin{array}{l}\text { balkon } \\
\text {-yemek yeme } \\
\text {-hava alma }\end{array}$ & $\begin{array}{l}\text { mobilyalar cok yer kapliyor. } \\
\text { esikik yaksekekigi } 8 \text { cm olup } \\
\text { gecisis imkansiz killyor. }\end{array}$ & 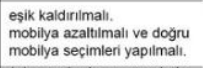 \\
\hline $\begin{array}{l}\text { banyo } \\
\text {-lavabo int. } \\
\text {-duş alma }\end{array}$ & $\begin{array}{l}\text { essikten dolayi gecis problemi var. } \\
\text { zemin kaygan. } \\
\text { tutunma ve destek problemi } \\
\text { dus teknesine ulasim }\end{array}$ & 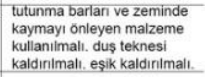 \\
\hline $\begin{array}{l}\text { kaçok banyo } \\
\text {-lavabo itht. } \\
\text {-dus alima } \\
\text {-el yikama }\end{array}$ & $\begin{array}{l}\text { esikten dolayy gecis problemi var. } \\
\text { zemin kayagn. } \\
\text { tutunma ve destek problemi } \\
\text { dust teknesine ulasim. } \\
\text { mekan cok dar. manevra zor. }\end{array}$ & 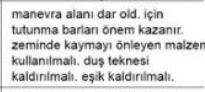 \\
\hline $\begin{array}{l}\text { odalar } \\
\text {-geçişler }\end{array}$ & $\begin{array}{l}\text { gorselde gorebilecegimiz } \\
\text { mobilyalar gecisiz zor hale } \\
\text { getiriyor. }\end{array}$ & problem çozoulebility \\
\hline
\end{tabular}

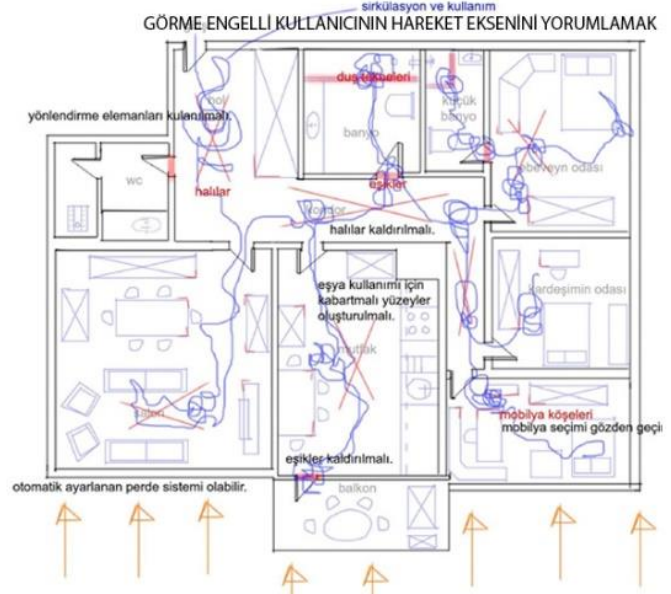

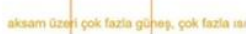

OLASI MEVCUT PROBLEMLER VE ÇOZOM ONERILERI

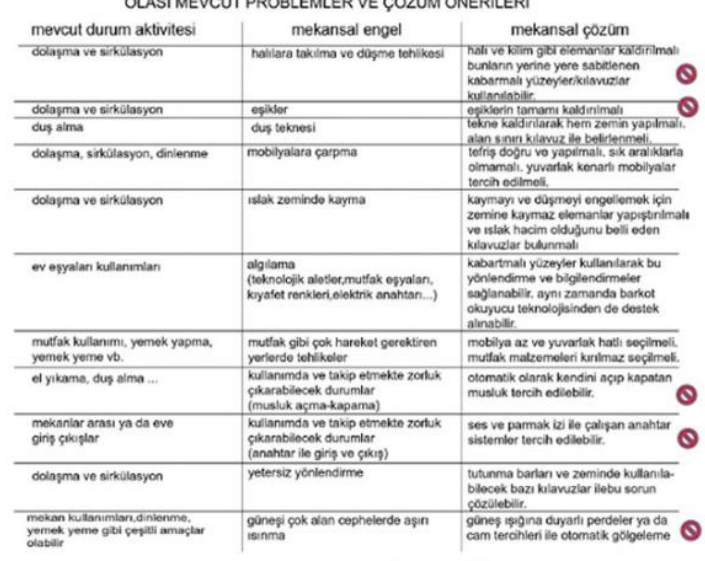

Lütfiye Kelleci Birer ile konuşmadan ònce oluşturduğum liste ( $)$ : Çok da gerek yok)

Figure 3 The students revised their analysis after meeting with the blind user

Then, in Stage 5, they met with a 51-year-old woman, blind since birth, in the online course. She lives with her husband and their 12-year-old son in their two-storey residence. During the online 
meeting with her, the students were expected to take part in question-driven discussions and analyses based on the real user's experiences. This stage was striking for them. Dialogue with her made the students informed about evidence-based design principles affecting their design decisions (Figure 3). Herein, they saw how their analysis and problem-solving approaches overlapped or conflicted as displayed by their comments below:

\begin{abstract}
"After listening to Birer, I noticed that there were differences in my approach... I observed that we could go astray while trying to think about every little detail and produce solutions... It is necessary to determine the order of priority and avoid unnecessary interventions while making interventions to a space... Conversations with the user before starting the design (as we did in our lesson) will strengthen the design... After that talk, I realized about previous works that we, as designers, either overestimate or ignore important things. However, as designers, we need to establish a good balance between the two of them." (M.B.)

"The interview gave me perspectives on what the design is, how often it is used, and the identity of the user in a space. I realized again that the first design idea and the site to be examined are important in this regard. Most of what the user said was what I thought and stated in my analysis, I was very happy about this, but I questioned myself about one thing. I realized that there is a problem of over-thinking in a space for the disabled, which is reflected as exaggerated designs. This can complicate the life instead of making it easier." (E.Ç.)
\end{abstract}

"Before listening to our guest, I thought that a blind person cannot live in a house with stairs. Our guest has minimized the danger by taking precautions in a house... She stated that as domestic users, they get used to the house, take the necessary precautions, and that they do not have any problems for themselves as long as the place of everything used is not changed. She stated that they had much more problems outside the home and that they were neglected." (C. Y.)

"No disabled person has problems in places where they are not strangers. This confirmed Mrs. Birer's statements. The important thing for us is to protect them from being a stranger and to organize the place in the simplest way to introduce and guide them easily." (G. V.)

"Before speaking to our guest... my research stated that many precautions should be taken, but after speaking (with her), I realized that we need to take enough and simpler measures rather than overprotective ones." (P. I.)

It can be concluded from the students' viewpoints that comparing their own experiences with the real user experiences caused them to critically evaluate and develop their studies. Through this dialogue, they saw that empathetic evaluation of their own house was not enough to (re)design a universally designed house. They grasped the UD principles of equitable access, simple and intuitive use to a great degree. They learned that optimum satisfaction of important safety requirements for all of us can provide a fair and liveable environment for the blind persons. In this context, ensuring the diversity of the dialogue environment, especially with the users of spaces, had a crucial impact on the success of distance education, which constructed a resilient learning environment in responding to the targeted knowledge acquisitions of the course.

Lastly, in Stage 6 and 7, they explored an inclusive house that they wanted to examine and made a comparative evaluation with their findings and UD Principles. In conclusion, they proposed inclusive design solutions to make their houses equitably used for all (Figure 4). 


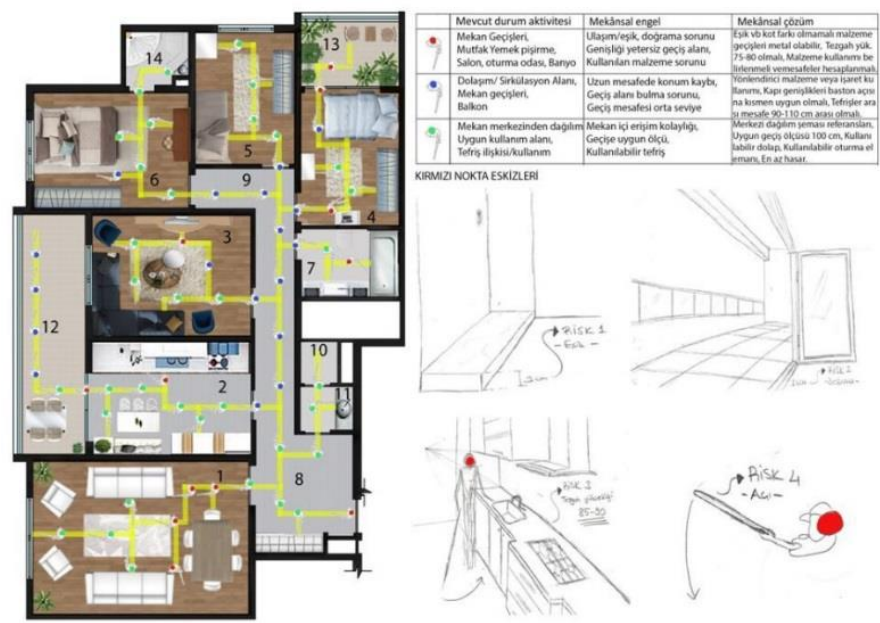

Page | 246

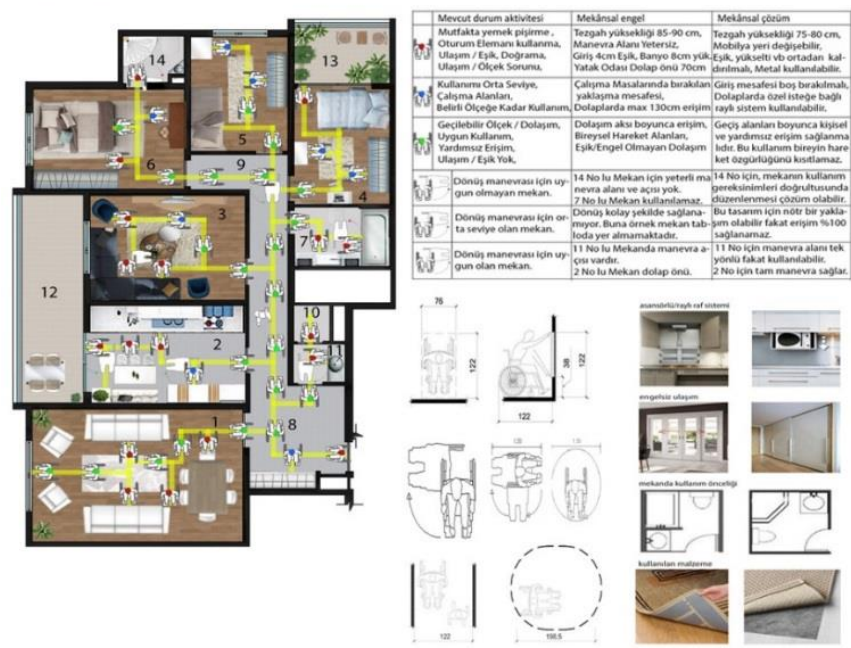

Figure 4 An example of the student's evaluation and inclusive design suggestions on her house

At the end of the course, all 16 students answered the question- "which task(s) have been instructive for you to internalize the Universal Design knowledge?". 15 out of 16 students, none of whom had communicated with a blind person until that time, stated that the lecture with the blind user was very impressive and informative about designing inclusive spaces. The other student indicated that he agreed with this idea and that it was also very beneficial for him to research exemplary inclusive houses.

For students, the most striking, effective, and permanent information emerged after meeting with the user with total visual loss. The students, who made some spatial suggestions after previous written, visual, and sensory experiences, seriously questioned their decisions when they met with her. This emphasis was that measures that are far from extremism and that are 'normal' for all, especially for security purposes, can adequately improve the house life for a blind individual. The students' statements widely display that they had vital knowledge of the design approach for universally designed built environments when they obtained the users' real-life experiences. It has been seen that the knowledge experienced with empathy is critically questioned and even this knowledge paves the way for propositions that lead to excess in design. Of course, meeting with a single user is not enough for designing an inclusive house. However, it is believed that they gained the knowledge and experiences of the inclusive design thinking process. In this sense, although a wheelchair user was not interviewed within the context of the lesson, it could shed light on hearing diverse user experiences, questioning their findings, and using an inclusive design approach to reach the best equitable spatial solution.

The UD learning in the hybrid education process allows the students to recognise the rational design thinking process which covers diverse evidence-based evaluation processes. Knowing how 
to manage the inclusive design process will be the greatest help in how to reach the best inclusive solution to any design problem they encounter in their professional life. Universal design assessment has a very important issue, which significantly affects creation of the spatial environment within the framework of the UD philosophy (Preiser, 2010). Especially when we look at the current design and application practices in Turkey, there are serious deficiencies in the evaluation of spaces according to the UD approach. Either incomplete or excessive accessibility practices can inhibit the design of equitable and safe spaces for everyone (Dinç Uyaroğlu, 2015). For this reason, it is thought that learning comprehensive spatial analysis methods and processes within the scope of the Universal Design course will significantly support the creation of inclusive spatial environments. Focusing on the "research/design by experiencing" instead of "design by doing" in the distance education process has been a profitable process in sustaining resiliency in design education. This study argues that the experienced UD learning process would equip students to transfer their ideas to the analysis of other design problems and processes in different cases.

It is no longer possible for post-pandemic normalization to bring about the same situation as in the past. Many conveniences, easy access to various sources, remote access to the classes or meetings, etc. taught by the pandemic have already settled in our education life, but the subject of learning by "sensing and experiencing in reality" for problem-solving and decision-making process will always remain at the desired point. This study agrees with the fact that the processes and experiences discussed in distance architecture education cannot be as successful as learning by doing/sensing within a real educational community setting (Cengizkan, 2021). Nonetheless, focusing on the experienced adaptive and transformative acts responding to the challenges could develop the learning process to the greatest extent possible.

\section{Conclusion}

Experiencing a process in which the Universal Design philosophy is internalized and dominated from the beginning to the end of the design process and during the implementation phase, instead of only complying with the design standards required by the law, will provide the formation of real inclusive spaces. However, as proven by the lived spaces in Turkey, accessibility can be thought of as a design issue that can be easily handled without the dialectic approach by applying existing standard knowledge superficially. The fact that it is not included in the education curriculum or emphasized in the learning objectives of the courses, especially design studios, may exclude the sufficient discussion of the UD concept. This narrow point of view can cause UD principles to be evaluated in a shallow perspective and thereby, can reduce the design-for-all approach to a separate 'disabled' ramp.

The Universal Design (UD) course based on equitable access and democratic life in the built environment is needed to develop students' socio-environmental responsibility by acquainting them with learning tools for analysing and evaluating the social, economic, and environmental circumstances (trans)forming our spatial world. In this way, it supports to make them informed and took decisions even with incomplete data and under uncertainty and contradictions. Sharing this responsibility in all interior architecture curriculum can lead students/professionals socially, politically, economically, and ethically in a complex world. In parallel with the ethical stance in the content of the course, it should be resilient to respond flexibly to any situation experienced during the education process.

For the resilient interior architecture education, it is necessary to create a program that will answer the questions (a) how Universal Design knowledge is veritably embedded in the interior architecture education curriculum and integrated into the learning and design process and (b) which learning tools can increase the knowledge acquisition and awareness on various ways of design implementations. The development of intellectual, behavioural, and practical attitudes of interior architecture students, who will be responsible for the formation of inclusive spaces of the future, should be the focus of the curriculum to answer these questions. The knowledge 
acquisitions of this thinking and design process are two of the primary issues in the dominance of the UD philosophy in design. In these aspects, this study aims to contribute to the formation of equitable spaces of the future by focusing on 'empathy', 'participatory observation', and 'close dialogue with users' in the UD learning.

Interior architecture education cannot be rootedly sustained without experientially interacting with the users, spaces, and environment. It is important for a resilient education that the curriculum has flexibility to involve required contents, learning models and processes opening up multiple dialogues among them so that the education and learning process could be conducted with the least loss in case of any difficulty. For the formation of more liveable, fair and sustainable environments, there is a great need for future studies on the UD learning tools, methods and processes in both face-to-face and distance architectural education. Adaptation to any transformative process can make the students prepared for deciding on critical issues responding to the quality of community life and protection of natural environment.

\section{Acknowledgement:}

The students who successfully followed ICM 384 Universal Design course in the 2020 Spring semester at Atılım University have a great share in the realisation of this study. I would like to thank each of them. Many thanks to Birer, who shared her spatial experiences with us during the online lesson. I am also grateful to both reviewers for their thoughtful comments and helpful suggestions.

\section{References}

Afacan, Y. (2011). Teaching universal design: An empirical research in interior architecture. Procedia Social and Behavioral Sciences, 15, 3185-3192.

Altay, B. \& Demirkan, H. (2014). Inclusive design: developing students' knowledge and attitude through empathic modelling. International Journal of Inclusive Education, 18(2), 196-217.

Brogden, L. (2020). From product to process and site to system: Disaster resilience and humanitarian design in architecture education (Doctoral dissertation). Retrieved from https://eprints.qut.edu.au/202988/1/Elizabeth_Brogden_Thesis.pdf.

Campos, P. (2020). Resilience, education and architecture: The proactive and "educational" dimensions of the spaces of formation. International Journal of Disaster Risk Reduction, 43, pp. 1-11.

Cassim, J. \& Dong, H. (2007). Designer education: case studies from graduate partnerships with industry. In R. Coleman, J. Clarkson, H. Dong, J. Cassim (Eds.), Design for Inclusivity: A Practical Guide to Accessible, Innovative and User-Centred Design (1st ed., pp. 71-87). England: Gower.

Cengizkan, A. (2021). Eğitim alanında "iletişmek" ve temel eksiklik: Beden dili ["Communicating" in the field of education and the main deficiency: Body language]. Yetkin Report. Retrieved from https://yetkinreport.com/2021/03/05/egitim-alaninda-iletismek-ve-temel-eksiklik-beden-dili/

D'Souza, N. (2007). Design intelligences: A case for multiple intelligences in architectural design. International Journal of Architectural Research, 1(2), pp. 15-34.

Dewey, J. (1916). Democracy and education: An introduction to the philosophy of education. New York: The Macmillan Company.

Dinç Uyaroğlu, i. (2015). Performance evaluation and design guidelines for equitable access of students with disabilities in university campus outdoor environments (Doctoral dissertation). Retrieved from https://open.metu.edu.tr/bitstream/handle/11511/25516/index.pdf.

Dong, H. (2010). Strategies for Teaching Inclusive Design. Journal of Engineering Design, 21 (2-3), $237-251$.

Duschl, R. A. (2012). The second dimension-crosscutting concepts: Understanding a framework for K-12 science education. Science and Children, 49 (6), 10-14.

Folke, C., Carpenter, S. R., Walker, B., Scheffer, M., Chapin, T., \& Rockström J. (2010). Resilience thinking: Integrating resilience, adaptability and transformability. Ecology and Society, 15 (4), 20.

Gehl J. (2011). Life between buildings: using public space $\left(6^{\text {th }}\right.$ ed.). Washington: Island Press.

Helvacioglu, E. \& Karamanoğlu N. N. (2012). Awareness of the Concept of Universal Design in Design Education. Procedia - Social and Behavioral Sciences, 51, 99-103.

Heylighen, A., Van der Linden, V. \& Van Steenwinkel, I. (2017). Ten questions concerning inclusive design of the built environment. Building and Environment, 114, 507-517. 
Imrie, R. (1996). Disability and the City: International Perspectives ( $1^{\text {st }}$ ed.). London: SAGE.

Imrie R. \& Hall, P. (2001). Inclusive Design: Designing and Developing Accessible Environments ( $1^{\text {st }}$ ed.). London: Spon Press.

Laboy F. \& Fannon, D. (2016). Resilience Theory and Praxis: a Critical Framework for Architecture. Enquiry The ARCC Journal for Architectural Research, 13(1), 39-53.

Ostroff, E. (1997). Mining Our Natural Resources: The User as Expert. Innovation, the Quarterly Journal of the Industrial Designers Society of America, 16(1).

Page| 249 Ostroff E. (2003). International design education strategies. In J. Clarkson, S. Keates, R. Coleman \& C. Lebbon (Eds.), Inclusive Design. London: Springer.

Ostroff, E. (2011). Universal Design: an Evolving Paradigm. In W. F. E. Preiser \& E. Ostroff (Eds.), Universal Design Handbook (2 ${ }^{\text {nd }}$ ed., pp. 1.3-1.11). New York: McGraw-Hill.

Preiser, W. F. E. (2010). Toward universal design performance assessments. In W. F. E. Preiser \& E. Ostroff (Eds.), Universal Design Handbook (2 ${ }^{\text {nd }}$ ed., pp. 38.1-38.8). New York: McGraw-Hill.

Rutter, M. (1993). Resilience; some conceptual considerations. Journal of Adolescent Health, 14(8), 626-631.

Strickfaden, M., Devlieger, P., Heylighen, A. (2009). Building Empathy through Dialogue Design Connexity. In J. Malins (Eds.), Eighth International Conference of the European Academy of Design Conference, 8 (pp. $448-452)$. Scotland: The Robert Gordon University.

Sungur Ergenoğlu, A. (2015). Universal design teaching in architectural education. Procedia - Social and Behavioral Sciences, 174, 1397 - 1403.

Trogal, K., Bauman, I., Lawrence, R., \& Petrescu, D. (2019). Introduction: architecture and resilience on a human scale. In K. Trogal, I. Bauman, R. Lawrence \& D. Petrescu (Eds.), Architecture and resilience: $a$ series of interdisciplinary dialogues ( $1^{\text {st }}$ ed., pp. 16-28). New York: Routledge.

Tutal, O. (2016). Yaşlılık, Yaşam Çevresi ve Evrensel Tasarım [Ageing, Sheltering and Universal Design]. In V. Kalınkara (Eds.), Disiplinlerarası Yaklaşım, Sorunlar, Çözümler-2 (1 $1^{\text {st }}$ ed., pp. 489-502). Ankara: Nobel Yayınları.

UNDRR (2021). Resilience. United Nations Office for Disaster Risk Reduction. Retrieved from https://www.undrr.org/terminology/resilience

Walker, B., Holling, C. S., Carpenter, S. R. \& Kinzig A. (2004). Resilience, Adaptability and Transformability in Social-Ecological Systems. Ecology and Society, 9(2), 5.

Waxman, H. C, Gray, J. P. \& Padron, Y. N. (2003). Review of Research on Educational Resilience. UC Berkeley: Center for Research on Education, Diversity and Excellence. Retrieved from https://escholarship.org/uc/item/7x695885

WHO (2001). International Classification of Functioning, Disability and Health. Geneva: World Health Organization.

Yılmaz, M. (2018). Public Space and Accessibility. ICONARP International Journal of Architecture and Planning, 6, 1-14.

\section{Resume}

Ilkay Dinç Uyaroğlu received BArch degree (2004) from Selçuk University, being awarded first-class honors. She earned her MArch (2008) and PhD (2015) degrees from the Department of Architecture, Middle East Technical University where she had extensive research and teaching experiences (2005-16). She has been conducting architectural design, basic design, interior design, and universal design courses since 2016. Her current research interests include architectural education, social sustainability, social inclusion, participatory design, and universal \& inclusive design. Since 2020, she has been working as an Assistant Professor at Ostim Technical University Faculty of Architecture and Design. 